\title{
Deconstructing the American Melting Pot: Promoting Civic Education and Ideals in the Bilingual Social Studies
}

\author{
Alberto López-Carrasquillo \\ Northeastern Illinois University
}

\begin{abstract}
This article reports the findings from a singlecase study with a first generation Mexicana Teacher in a bilingual social studies classroom in an elementary school in the Midwest United States. The aim of the study was to understand how she plans a social studies curriculum for her Latino students that deconstruct the general idea of the American society as a melting pot. Findings reveal that she expands the curriculum to include the culture of Latino students and support the formation of a bicultural identity. By implementing what I called a culturally position planning, this Latina teacher epistemologically defines herself and the students to implement a curriculum that is critical in promoting a civic notion about the national identity.
\end{abstract}

\section{Introduction}

By the 1890's, cultural deficiency and assimilationist theories were commonly used by social scientist in the effort to understand the social changes in the United States due to new waves of immigration. By the 1900's when many Americans were only one generation apart from being of immigrant descent themselves, nativist movement began that claimed that the old-stock American values and social patterns were preferable to those of immigrants. Consequently, new immigrants were expected to set aside their distinctive cultural identities to be absorbed or fully assimilated into a homogeneous culture, a melting pot [1]. Nativists feared that immigrants posed a threat to "American" traditions they valued and considered "the real American values." Hence, by the end of the $19^{\text {th }}$ century and the beginning of the $20^{\text {th }}$ century, nativists promoted the assimilation of newly-arrived immigrants mostly Germans, Irish, Norwegians, and other immigrants around the world. By the 1920's, these perspectives continued evolving and influencing various fields in the production of knowledge, up to the point of developing cultural deficiency theories to describe cultural and ethnic differences. Cultural deficiency or assimilationist theories [2] became more common even in explaining a biological determination that favors the culture and social patterns of Anglos over those of new immigrants. She added that "the underlying premise of biological deficiency theories was that non-Anglo Americans, including Mexicans and Puerto Ricans, were biologically different and inherently inferior to Anglos" (p. 29).

In contrast, multiculturalism is an idea that challenges the nativist vision of the United States. The Civil Rights Movement of the mid twentieth century marked the time when minority groups stood up against these oppressive structures to claim their right to be different from the mainstream. Sleeter and McLaren [3] explain that during this era many African-American scholars and educators coined the term "multiethnic education" to start linking racial and ethnic groups (p. 17). Later, this term was broadened to "Multicultural Education" to include gender and other forms of diversity. Sleeter and McLaren [3] argue that, rather than celebrating "ethnic food" and festivals, multicultural education should be used as a framework to understand inequalities in "terms of institutionalized oppression and [that the framework] reconfigures the families, and communities of oppressed groups as sources of strength" (p. 18). The idea of multiculturalism contrasts with the melting-pot construction by visualizing the U.S society as a salad bowl, which is diverse and pluralistic in nature. Banks [4] explains that the first phase of multicultural education emerged when educators interested in the history and cultures of minority groups started to infuse theories and ideas from ethnic groups into the school curriculum. This first phase was followed by the second phase Sleeter and McLaren described as "multiethnic education" [3]. According to Banks this second phase [4] emerged when educators interested in ethnic studies realized the limitations of only infusing ethnic studies in the curriculum; hence the goal of multiethnic education was to promote structural and systemic changes in the entire schooling system and to promote educational equality.

These bifurcated socio-cultural perspectives have influenced the formulation of school curriculum. On one hand, there are curricular theorists who argue that it is vital for public schools to support a national identity by promoting the assimilation of immigrant students into embracing "mainstream values" [5]; and see the increasing diversity within the United States as a problem to be solved [6]. This means that assimilationist perspective has permeated the 
thinking of teachers and many teaching practices. For example, Larson [7] found in her case study in a kindergarten classroom that reading events in the classroom she observed were "limited to read outloud, in which the teacher selected the books, read them to the class as a whole, and periodically asked prediction questions" (p. 97). What Larson claims is that there is a common discourse practice in white middle-class families that is consider neutral and "best practices" of teaching consequently excluding from the "official curriculum" other forms of literacy practices that are more culturally suitable for students from minority groups, such as storytelling.

On the other hand, theorists who promote multicultural education argue that school curriculum should respect the diversity within a pluralistic society, and should promote the infusing of students' cultural knowledge as a relevant aspect of the curriculum [8]. Multicultural education promotes a concept of civic identity that is not ethnically inherent to any particular cultural group within the society. In this multicultural society, citizens choose which civic values are more desirable to maintain the social structures established in the constitution and the founding documents of the United States. This multicultural society aspires to develop a citizenship consciousness that is based on what Ignatieff [9] defines as civic nationalism:

Civic nationalism defines a nation in terms of people regardless of race, color, creed, gender, language, or ethnicity - who subscribe to the nation's political creed. This nationalism is called civic because it envisages the nation as a community of equal, rights-bearing citizens, united in patriotic attachment to a shared set of political practices and values. (p. 6)

Creating this civic nationalism might be the base of a multicultural and pluralistic society because the national identity will be based on civic principle rather than ethnic characteristics. Multicultural education envisions a society in which all ethnic and cultural groups are respected; a society that values equality, social justice and the pursuit of happiness regardless of ethnic characteristics or inherent.

How social studies teachers teach the notion of citizenship and civic identity is an area from the research that needs attention. In light of this interest, this article reports how a Latina teacher uses students' cultural knowledge as a vital component for her bilingual social studies classroom. For this reason, the aim of this single-case study was to gain an understanding of how this first-generation Mexicana teacher plans curriculum to promote a multicultural education and prepare her Latino students to be effective and participatory members of a democratic and pluralistic society.

\section{Theoretical Framework.}

This study was aligned with Latino Critical Theory (LatCrit.) [10]. This theoretical framework attempts to explain the pan-ethnic experiences of Latinos in the United States. LatCrit. extends the work of Critical Race Theory (CRT), an approach born out of critical legal studies, by focusing on the issues of Latino communities in the United States. Howard [11] argues that the inclusion of a critical race framework is needed in education, considering the perennial underachievement records of African American, Latino/Latina, Native American and Asian American students in U.S. schools.

LatCrit has emerged as a well-developed system of knowledge or epistemology that challenges the dominant Euro-American epistemological paradigm [8]. Delgado-Bernal [10] explains that LatCrit is concerned with a progressive sense of pan-ethnic experience that is often ignored by other critical theorists, such as: language oppression, immigration issues, cultural identity, phenotype, and sexual identities. Scholars who promote the LatCrit. approach have established a framework that contrasts with the Euro-American mainstream ideology. The LatCrit. perspective challenges the mainstream ideology which promotes the Americanization of immigrants by imposing hegemonic practices such as promoting English-language instruction, a practice that restrains the culture and language of Latino/a students. Understanding the intersection of these identities is vital for the LatCrit. perspective in describing the pan-ethnic experiences of Latinos in the United States.

\section{Methodology and data analysis.}

This study implemented qualitative methods of data collection in alignment with a single-case study design [12]. Journal writing, making file observations, and member check [13] were the methods used in accord with the inherent characteristics of triangulation to secure an in-depth understanding of the phenomenon in question. .

The primary participant of this single-case study is a first generation Latina Teacher, hereafter called Grisel. Through knowledge of the Latino/a teaching community in the Chicago area that I had, I was introduced to teachers. I had informal conversations with many teachers and from these informal conversations they had shared with me their concerns about the status of the education system. These informal conversations helped me gain access to potential participants for my study.

I developed three criteria that participant of this study should meet: 1) The participant should identify 
himself or herself as a first generation Latino/a teacher; 2) he or she should be teaching a social studies teacher in an elementary school; and 3) he or she should be compromised with teaching for diverse students, especially Latino students. These criteria ensured that the sample will be rich in information and accord with the purpose of the study. La Maestra Grisel met these criteria; hence, I formally invited her to be part of this study. She gladly and enthusiastically accepted. Grisel was very enthusiastic and always willing to talk about her experiences as a teacher. She was commonly identified by her colleagues as very highly committed to teaching her diverse students, mainly Latinos/a students. Before coming to the United States, she taught for 6 years in the northern state of Chihuahua, Mexico. Later in her professional career, she participated in a teacher exchange program in one of the school district of the Midwestern States where the population of Latino/a students has increased significantly.

Once I collected the data, the general strategy of relying on the theoretical propositions [12] was implemented in order to uncover patterns and themes. These methods of data collection and analysis helped me to answer the following research questions: The uses of specific methods were guided by the following questions: (1) How did this teacher plan? (2) What did the planning look like in action (i.e. teaching)? (3) What factors significantly impacted planning decisions (the teacher's race and culture, the teacher's gender and the contextual nature of the school)? (4) What specific experiences contributed most to her thinking and planning? and (5) what was the relationship between this planning and its teaching?

\section{Planning for a salad bowl society: deconstructing the melting pot.}

Grisel's sources of Cultural Comprehensive Knowledge [14] affect the way she plans and makes decisions. Milner defines Culturally Comprehensive Knowledge [14] as "an accumulation of the multiple experiences that shaped how this teacher understood the world" (p. 176). Hence, her experiences as a Latina first generation immigrant among other identities shape her understanding of the world. These worldviews are translated into her planning through a process that I called culturally positioned planning. This consists of defining who the teacher is and who the students are according to what experiences are included in the teacher's cultural comprehensive knowledge. These two elements were fundamental in developing a social studies classroom that promotes the ideas of a multicultural and pluralistic society, thus, preparing the students to live in a salad bowl society and deconstructing the melting pot. Three main strategies Grisel uses to do this: a) expanding the curriculum, b) using home' culture, and c) fostering biculturalism.

\subsection{Expanding the Curriculum}

Grisel knows firsthand that the Latino home culture plays in important role in how students see themselves and the world; therefore, she develops plans that include it at much as possible. For example, as a part of the official curriculum, she developed a unit plan to study the national symbols of the United States. In this unit, she changed the curriculum in order to include the national symbols from Mexico, Chile, and El Salvador, which are the countries that are represented in the classroom, and to study problems of living in Mexico City.

\section{...this is a change in curriculum that I must do, comparing the US national symbols to their countries.....the unit is about Mexico City and the problems they have, like pollution...Before beginning to discuss the problems that a big city has, one has to see the history of Mexico, how the city was founded. But they [the textbook] discuss it in two paragraphs. Then, for my Latino population, for me... as a citizen of Mexico...it is very important that my students know from where their parents came from because they [the students] were born here. (Grisel, Interview, March 10, 2006)}

During both her short-range planning, long-term and the interactive planning process, she makes curricular changes to include issues that she considers vital for her Latino students to know for being active and informed citizen of the United States, and knowing and understanding their cultural and historical heritage as Mexican-Americans.

Expanding the curriculum shows how Grisel challenges the official curriculum and claims a professional autonomy to make the curriculum culturally relevant and critical. Here she is creating a curriculum that is resistance and opens a social space that promotes a historical consciousness that is culturally relevant. Comparing the national symbols and history of US and Mexico is a negotiation of the traditional structures that insists on the assimilation of immigrant students, thus creating a social studies curriculum that promotes what Solorzano and Bernal called transformational resistance [15].

\subsection{Including home culture}

Immigration is part of the pan ethnic experiences of Latino in the United States, and central to the nativistic views of the United States. For nativists immigration represents a major threat to the cultural 
values of the mainstream. On the other hand, immigration is the strength of the United States as a multicultural and pluralistic society. In this bilingual social studies classroom, Grisel promotes the multicultural views of the American society by including the home culture. In many of these Latino families, the issue of immigration is discussed in the regular basis.

Grisel's cultural comprehensive knowledge allows her to be familiar with some of the realities of the home culture as children of immigrant parents. What is more, she knows firsthand many of these experiences because she is also an immigrant. Hence, she plans to discuss issues of immigration with her students.

We were speaking of immigration, of the types of immigration or the reasons for which people immigrate, then the parents along with the children made a type of essay in where they gave the reasons for which they came to the US. Most of them came to get better jobs or for a better education. Because in Mexico although one assumes that the education is free according to the third article of the constitution, it is not totally free... Then that education that is free and obligatory in Mexico is in fact not. Then for people with few economic resources, as most of the family parents we have, they have three or four children to raise, then in reality they cannot provide school for them, or even give them inscription that is supposed to be not obligatory... so that is one of the reasons for which those families also immigrate. Because they have so many children and cannot keep them in school. They prefer to immigrate because here you know that they are not going to be requesting things from you [the school] all the time (Grisel, Interview, April 28, 2006)

Grisel identifies two reasons parents of her students decided to immigrate to the United States: better jobs and more educational opportunities for their children. What is more, she uses her experiences as a former teacher in Mexico to understand the problems of accessibility to education that parents face, leading them to emigrate; thus she uses her cultural comprehensive knowledge to bridge the students' home culture and official knowledge [16].

\subsection{Fostering biculturalism}

Grisel understands that her students are bicultural; therefore, it is vital for them to know about both countries. The unit plan about National symbols also serves to foster the bicultural identity of her students. By broadening the scope of the social studies curriculum in the areas she feels the curriculum is weaker, she achieves to position the social studies curriculum closer to the needs of her Latino students. She explains:

...this is a change in curriculum that I must make, comparing the national symbols of their country. In fact, [students] belong to two countries and most of the students when we see their identity, about the culture, to what culture they belong, because they spoke to me of their culture, through the project they did together with their parents, I realized what cultural identity they have or their inclination to which cultural identity. Then, it would be a disaster and an error for me to not see the other culture. There are some that identified themselves with the two cultures; there are some that identified themselves as Americans. It is why I need, for those many or those few that are identified with both cultures, because if their nationality is both, they need to know about Mexico, or Chile-well the one from Chile identified himself as American-but for example, El Salvador, the one from El Salvador, she identifies herself as Salvadoran and American. (Grisel, Interview, March 10, 2006)

This type of change to the bilingual social studies curriculum that Grisel does, it is related to her ideological clarity. She knows the political, economic, and social realities of the Latino community. In light of her understanding of the Latino community, she has what Bartolomé and Barderrama call teacher ideological clarity [17] and what Calderhead notes in term of how the planning process occurs [18] within a practical and ideological context. This means that the understanding that Grisel has about the Latino community and its realities comes from her cultural comprehensive knowledge. To her, her job is not "mainstreamed" the Latino students into the "dominant culture"; on the contrary, her job is to teach them the "mainstream culture" as well as to teach them their native culture. Grisel points out: ...Like I said to them [her Latino students], you have the most wonderful fortune of the world because you have the Mexican part and the American part. You are two cultures in one person. Let's see, if you have a donut here only with sugar, and if you another donut here with sugar, caramel, and then stuff with vanilla, which one you are going to like? Well, the second one-why? Because it's more delicious. Aha, well suppose you are that culture. It is not only the donut; it is everything that comes with the other culture.) (Grisel, Interview, January 18, 2006)

Grisel's ideological clarity allows her to challenge the nativistic purpose of the emerging of an ethnic nationalism by the assimilation of immigrant students. Thus, this ethnic nationalism promotes the normalcy of the White Eurocentric privileges. When Grisel discusses with her students 
the advantages of having a bicultural identity, she is changing a history of oppression that segregated Mexican students from White students for considering them "genetically and physically inferior", prohibits Spanish-language, and uses local and states officials to maintain and justifies a colonial relation between Mexican and the mainstream society [10]. By fostering a bilingual identity Grisel is disrupting the dominant ideology that promotes the hegemony of cultural assimilation as the way of being a "real American" over the development of a bicultural identity as valid way of being a "real American" as well. Discussing issues of identity helps students understand that being bicultural does not represent a problem or a deficit that only the assimilation and suppression of the home culture will remediate.

\section{Implications and Conclusion.}

Planning is not a neutral act; teachers' culture, ideology and epistemology are parts of the elements considered during the decision making process. In Grisel case, she plans a social studies curriculum taking into consideration her identity as a first general Latina and the position of her Latino students a minority group. In this sense, she was conscious of the realities of the Latino community her students and her are part of, languages issues, and other pan ethnic experiences. From this unique epistemological stance, she planned and made instructional decisions in the bilingual social studies classroom.

Grisel's culturally comprehensive knowledge and culturally positioned planning helped her to take a historical and ideological position in defining the American identity from a civic nationalistic standpoint. By extending the social studies curriculum to include the history and national symbols of the original countries of the Latino students, she fosters that these students do not lose their cultural heritage -including their languageand using their home culture as a strength and not as a problem. By changing the curriculum, Grisel promotes a multicultural education that deconstructs the melting-pot visions of the nativists by promoting a civic education curriculum that disrupts the official curriculum.

In this bilingual social studies classroom, these Latino students learn that: a) there is nothing wrong with being Latino; b) they do not have a deficiency for being Latino; c) they cultural heritage and language is a strength and not a problem; d) being an American does not imply to give up who they are; and that e) America is a salad bowl society in which each society is an important part in the great flavor of being an American.

The idea that there is nothing wrong with being Latino is important for these students in order to develop a positive self-image about their cultural identity. Recently, showing a positive image is vital for these students in light of the 2010 Arizona SB1070 Law and the increasing anti-immigrant -especially anti-Latino - sentiment. In this classroom, students reaffirm who they are and the teacher encourages them to see their culture as a source instead of a problem that needs to be remediated by assimilation. Thus, Grisel fosters that civic and democratic ideals are what tied the country together.

In this sense, she challenges the notions of ethnic nationalism that nativists insist in using when defining who is a real American and who is not. This national identity based on cultural and ethnic characteristics was commonly used during the colonial era until the post World War II. In the post WWII Era a new understanding of the nation identity started to emerge as the civil rights movements of the 1960's and the facto segregation ended in the U.S. Southerner States when congress passed and Presidents J.B. Johnson firmed into a law the Civil Rights Act of 1964. This new identity started to be based on civic ideals reshaping and deconstructing the idea of a meting-pot that promotes the cultural assimilation of minority groups, especially first generation immigrants. This new civic identity presented a new image of nation as a salad bowl as described in the literature. This new perspective of the country envision a national of nations, culturally speaking, where the ties that hold the nation together are based on the ideals emanating from the constitution, the republican form of government and the rule of law. These are the values that are important in a national identity that is based on civic ideals. Since the 1960s this perspective of a national identity has permeated the school classroom around the country, especially social studies classroom such as Grisel's.

Grisel's social studies classroom is a space in which counter-storytelling serves as pedagogical tools that resistance socio cultural constructions of who are the "real" Americans, and distinguishes between civic notions from ethnic notions of civic education. What is clear in this single case study is that Grisel's students are learning English as well as other children of immigrants in the history of the United States, and the civic ideals of the American society that the National Council for the Social Studies (NCSS) promotes. The NCSS is a national organization that agglomerates researchers and teachers of social studies in the United States; they state that:

An understanding of civic ideals and practices of citizenship is critical to full participation in society and is a central purpose of the social studies. All people have a stake in examining civic ideals and practices across time and in diverse societies as well as at home, and in determining how to close the gap between present practices and the ideals upon which our 
democratic republic is based. Learners confront such questions as: What is civic participation and how can I be involved? How has the meaning of citizenship evolved? What is the balance between rights and responsibilities? What is the role of the citizen in the community and the nation, and as a member of the world community? How can I make a positive difference?

In this sense, these Latino students in Grisel's bilingual classroom are learning what defines the American society as a civil society without sacrificing their home culture and ethnic heritage.

Furthermore, the case of Grisel has the potential to shed light to the importance of implementing a culturally relevant pedagogy in reducing the curricular gaps between White-middle class students and students of color from economically disadvantage communities. She was intentional in promoting a curriculum that interrogate and challenges the official curricular boundaries of knowledge by taking an ideological stance that is firm in affirming that citizenship and national identity do not have to compromise the Latino cultural identity. Thus, moving the curriculum closer to her students' cultural experiences.

Darder points out that despite many years of education reforms [19], Latinos in the United States continue experiencing difficulties in adapting to the traditional expectation of the public schools, and the cultural norms and standards that influence the schooling process. For example, cultural conflicts between the school and home, language barriers, stereotypical attitudes toward multicultural education and teachers who are ignorant about the realities Latinos students face, and bilingual programs that fail to support the development of genuine bilingualism are a few of the barriers that contribute to the achievement gap.

These barriers along with the myth that the United States is a meritocratic society further exacerbate the school experiences of the Latino students. Ochoa argues that this myth fosters the assumption [2] that students who do not perform well in school are to blame because they are lazy and do not have the intellectual capacity or their parents do not value education as their counterparts from White-middle class suburban communities. Grisel is explicit in deconstructing this narrative of her Latino students by expanding the social studies curriculum to go beyond the official expectations. She changes the curriculum in a way that is culturally relevant for her students helping them work hard, but to work for what is meaningful for them, for example when she changed the curriculum to include some of the national symbols of Latin American countries.

In sum, as Grisel uses her culturally position planning, she is able to remove curricular barriers and promote an education that does not blame the students and their communities for problems that are rooted in historical understandings and social inequalities. What is more, she is teaching a civic education that promotes social equality and justice by challenging the nativistic perspective that advance the ethnic culture and ideology of "the mainstream" group and suppresses the cultures of new immigrants. Furthermore, by changing the social studies curriculum, Grisel is deconstructing what the current neoconservative movement envisions the school curriculum, especially social studies, should teach; as Toll [20] argues:

"This focus on "cultural literacy" aims to provide all students with a common, value-laden culture. The curriculum supports "traditional" roles of women and other oppressed groups and creates in students an understanding that one correct interpretation of what they read or what they experience exists. (p. 354)"

In other words, the U.S. is facing a curricular crisis. A curricular crisis that is diminishing the purpose of education within society, and treating teachers as bank employees that their only purpose is to sell and achieve pre-established goals by reading a script previously written by "those who really know what is best for children". In light of this, we need more teachers like Grisel. The nation needs teachers who are ideologically conscious and who are willing to reclaim their professional autonomy on behalf of their students.

\section{References}

[1] Berkin, C., et al. (2008) Making America: A History of the United States Vol. 2: Since 1865. 2008, Houghton Mifflin Company, Boston

[2] Ochoa, G. L. (2007) Learning from Latino Teachers, Jossey-Bass, San Francisco.

[3] Sleeter, C. E. and McLaren, P. (2009) 'Origins of Multiculturalism', in Rethinking Multicultural Education: Teaching for Racial and Cultural Justice, Rethinking Schools Publications: Milwaukee, WI, pp. 17-19.

[4] Banks, J. A. (2001) Multicultural education: historical development, dimensions, and practice' in Handbook of Research on Multicultural Education, Jossey-Bass: San Francisco, CA, p. 3-24.

[5] Yoshino, K. (2006) 'The Myth of the Mainstream', The Chronicle of Higher Education, pp. B11-B12.

[6] Huntington, S. P. (2004) Who are we: The Challenges to America's National Identity, Simon \& Schuster, New York.

[7] Larson, J. (2003) Negotiating race in classroom research: tension and possibilities, in Making Race Visible: Literacy Research for Cultural Understanding, Teacher College Press: New York City, New York, pp. 89-106.

[8] Ladson-Billings, G. (1995) 'But That's Just Good Teaching! The Case for Culturally Relevant Pedagogy', Theory Into Practice, (34), pp. 160-165.

[9] Ignatieff, M. (1993) Blood and Belonging: Journeys into the New Nationalism, Farrar, Straus, and Giroux, New York. 
[10] Delgado-Bernal, D. (2002) 'Critical Race Theory, Latino Critical Theory, and Critical Raced-Gendered Epistemologies: Recognizing Students of Colors as Holders and Creators of Knowledge', Qualitative Inquiry 8(1), pp. 105-126.

[11] Howard, T. (2003) 'The dis(g)race of the social studies', in Critical Race Theory Perspectives on the Social Studies: The Profession, Policies, and Curriculum, IAP Information Age Publishing: Greenwich, Connecticut, pp. 27-43.

[12] Yin, R. K. (2003) Case study research: Design and methods (3 ed.), Applied Social Research Methods Series. Vol. 05, SAGE Publications Inc, Thousand Oaks.

[13] Merriam, S. B. (1998) Qualitative Research and Case Study Applications in Education, Jossey-Bass, San Francisco.

[14] Milner, H.R. (2003) 'A case study of an African American English teachers' cultural comprehensive knowledge and self-reflective planning', Journal of Curriculum and Supervision 18(2), pp. 175-96.

[15] Solorzano, D. G. and D. D. Bernal (2001) 'Examining Transformational Resistance Through a Critical Race and Latcrit Theory Framework: Chicana and Chicano Students in an Urban Context', Urban Education 36 (3), pp. 308342.

[16] Apple, M. W. (2002) Official Knowledge: Democratic Education in a Conservative Age, Routledge, New York.

[17] Bartolomé, L. I. and Barderrama, M. V. (2001) 'The need for educators with political and ideological clarity', in The best for Our Children: Critical Perspectives on Literacy for Latino Children, Teachers College Press: New York City, NY. pp. 48-64.

[18] Calderhead, J. (1996) 'Teacher: Beliefs and Knowledge', in Handbook of Education Psychology, Macmillan Library Reference USA, New York City, NY, p. 709-725.

[19] Darder, A. (2007) 'Radicalizing the Immigrant Debate in the United States: A Call for Open Borders and Global Human Rights'. New Political Science 29(3), pp. 369-384.

[20] Toll, C. A. (2002) 'Critical and Postmodern perspectives on School Change', Journal of Curriculum and Supervision 26(4), pp. 345-367. 